\title{
FOXA1 wt Allele
}

National Cancer Institute

\section{Source}

National Cancer Institute. FOXA1 wt Allele. NCI Thesaurus. Code C101647.

Human FOXA1 wild-type allele is located within 14q12-q13 and is approximately $10 \mathrm{~kb}$ in length. This allele, which encodes hepatocyte nuclear factor 3-alpha protein, is involved in transcriptional regulation. Aberrant expression of the gene is associated with several cancers. 